\title{
Antimicrobial Activity of Some Synthetic Compounds on Fungi Associated with Post Harvest Rot of Red Pepper (Capsicum annum)
}

\author{
Matthew O. KOLAWOLE', Ibikunle I. ANIBIJUWON ${ }^{1}$, David O. \\ ADETITUN $^{1 *}$, Shola K. BABATUNDE², Efuntoye ANJORIN ${ }^{1}$ \\ ${ }^{1}$ University of Ilorin, Department of Microbiology, Infectious Diseases and Environmental Health Laboratory, P.M.B. 1515, Ilorin, Nigeria \\ ${ }^{2}$ Kwara State University, Biotechnology and Biological Sciences Department, Malete, Nigeria; adetitun.do@gmail.com ( ${ }^{*}$ Corresponding author).
}

\begin{abstract}
Rhizopus sp, Mucor sp, Collectotrichum capsici and Geotrichum candidum were isolated but pathogenic test revealed that Collectotrichum capsici and Geotrichum candidum were the most pathogenic of all the isolates. $\mathrm{Ni}^{2+}+$ Azo has the highest inhibitory effect, closely followed by $\mathrm{Ni}^{2+}+$ PAN while Copper (II) complex of Thiourea has the lowest inhibitory effect. However, $10 \mathrm{mg} / \mathrm{ml}$ concentration proved to be the most effective when radial mycelial growth of the test fungi was measured. The inhibitory effects of each complex on the isolates increases with increase in incubation period. There is the feasibility of using synthetic associated with the symptoms. The three synthetic compounds, Copper (II) complex of Thiourea, $\mathrm{Ni}^{2+}+$ compounds as preservatives for harvested red pepper.
\end{abstract}

Keywords: Collectotrichum capsici, fungi, mycelial growth, red pepper, synthetic compounds

\section{Introduction}

Pepper (Capsicum sp.) belongs to the family Solanaceae. The two original species of Capsicum recognized by King (1974) and Purseglove (1991) are Capsicum_annum L. and Capsicum frutescens $\mathrm{L}$. The common types of pepper found in the Nigerian market include those with long pointed fruit (Yoruba - Shombo), those with small pointed fruit (Yoruba - Atawewe), those with large and fat bell shaped fruit (Yoruba - Tatase) and those with round wrinkled fruits (Yoruba - Rodo). The first two are classified as Capsicum frutescens while the others are classified as Capsicum annum (Fagbemi and Soyinka, 1988).

Post-harvest diseases destroy $10-30 \%$ of the total yield of crops and in some perishable crops especially in developing countries, they destroy more than $30 \%$ of the crop yield (Agrios, 2005; Kader, 2002). Post harvest rottening of red pepper has been a major problem to growers of pepper in Nigeria because it is perishable in a very short period of time due to infestations by microorganisms. International agencies that monitor world food resources have acknowledged that one of the most feasible options for meeting future food needs is reduction of post-harvest losses (Kelman, 1985). Although, many chemicals have been used in the past to protect the fruits against microbial spoilage, but most of them are only microstatic and very toxic to man and animal (Avakyan, 1974). Some of such chemicals that have been previously used include $\mathrm{Pb}$, $\mathrm{Zn}, \mathrm{Fe}, \mathrm{Cr}$ and a host of others (Avakyan, 1974; Luken, 1971; Marsh, 1977).
Hakan et al. (2009) reported that Thiourea derivatives and their Nickel and Copper complex showed antiyeast activity with (minimum inhibitory concentrations (MICs) between 25 and $100 \mu \mathrm{g} / \mathrm{cm}^{3}$. The effectiveness of Nickel salt against rust fungi was first demonstrated in 1958 and in the following decade, fungicide employing $\mathrm{Ni}^{2+}$ as an active ingredient were among the few known, that could be used to control such disease. Mont rust, Sunflower rust, black stem rust of wheat, crown rust of oats were all shown to be sensitive to $\mathrm{Ni}^{2+}$ salts (Marsh, 1977). A commercial formulation known as Dithane S-31, containing $33 \% \mathrm{NiSO}_{2} \cdot 6 \mathrm{H}_{2} \mathrm{O}$ and $66 \%$ Maneb (a wettable powder) was marketed by Rohn and Hass for the control of this rust disease.

The non-toxic nature of Nickel to animals was demonstrated when metallic Nickel given orally appears to be non-toxic, dogs and cats tolerating $12 \mathrm{mg} / \mathrm{Kg}$ for more than 6 months with no diverse effects (Stokinger, 1963). Nickel as the carbonate soap, or catalyst form had no impact on growth rate when fed to young rats at level up to $1000 \mathrm{ppm}$, nor did this exposure regimen with monkeys over a 6-month interval affect growth, behavior or haematological indexes (Phatak and Patwardhan, 1985).

This study is undertaken to survey the range of fungi associated with post-harvest rot of red pepper (Capsicum annum) with a view to reducing the menace of the isolated pathogen with the use of synthetic compounds that will be microcidal in action and less toxic to both animal and man. In this work, the three chemical complexes were subjected to fungicidal assay test and their toxicity was deter- 
46

mined by measuring the size of the colony attained in a certain period of time.

\section{Materials and methods}

\section{Sample collection}

Diseased samples of local pepper fruits were collected from three different selling points at the main campus of the University of Ilorin, Nigeria. The samples were brought in separate clean polythene bags for examination and isolation of organisms PAN and $\mathrm{Ni}^{2+}+$ Azo were supplied by Prof J.A Obaleye of the Chemistry Department, University of Ilorin, Nigeria.

\section{Culture media}

Pepper dextrose agar was prepared by grinding 50 grams of healthy pepper fruits, after which it was filtered using sterile cellophane cloth. The filtrate collected was made up to $250 \mathrm{mls}$ using sterile distilled water. Five grams $(5 \mathrm{~g})$ of dextrose and technical agar were then added one after the other. The mixture was then sterilized by autoclaving at $121^{\circ} \mathrm{C}$ for 15 minutes. The medium was allowed to cool after which $0.25 \mathrm{~g}$ of streptomycin was added.

\section{Isolation and identification}

The test organisms were isolated from diseased pepper fruits using the blotter method. Characterization and subsequent identification were based on the colonial and microscopic observation with the aid of standard mycological guides (Anna, 1990; CMI, 1985, 1988).

\section{Pathogenicity test}

This was carried out by using the Koch's postulates. Disease development was assessed by visual estimation as described by Croxal et al. (1952).

\section{Incorporation of the synthetic compounds and} determination of mycelial growth

One milliliter $(1 \mathrm{ml})$ of each of the different concentrations of the test chemicals was pipetted into sterile plates. After the medium has been properly mixed, it was allowed to solidify. A sterile cork borer $(0.4 \mathrm{~mm}$ in diameter) was used to remove inoculum plugs from the advancing edge of a pure culture of the organisms. The plugs were transferred aseptically in an inverted position with the aid of a sterile scalpel to the centre of the growth medium and incubated at room temperature $\left(27^{\circ} \mathrm{C}\right)$. Another plate used as control was inoculated with the test organism for comparison. Radial growth was determined at a minimum of 24 hrs interval for five days. Mycelial growth was determined by measuring the diameters of mycelia produced along two perpendicular axes marked on the bottom of the plates. The diameter of the inoculum plug was subtracted from the readings to obtain the actual radial diameter of growth.

\section{Determination of percentage inhibition}

The percentage inhibition of the chemical complex was deduced from the formula:

$\%=\frac{X-Y}{X} \times 100$

where

$\mathrm{X}=$ Radial growth on control plates

$\mathrm{Y}=$ Radial growth on treated plates

\section{Results}

Rhizopus sp, Mucor sp, Collectotrichum capsici and Geotrichum candidum were the fungi isolated (Tab. 1). The results of the pathogenicity tests revealed two of the isolated fungi as the most pathogenic. They were identified as Geotrichum candidum and Collectotrichum capsici.

The effect of the three chemical complexes on the growth of Geotrichum candidum and Collectotrichum capsici are shown in Fig. 1 to Fig. 6. The results showed that $\mathrm{Ni}^{2+}+$ Azo has the highest inhibitory effect, closely followed by $\mathrm{Ni}^{2+}+$ PAN while Copper (II) complex of thiourea has the lowest inhibitory effect. Also, a $10 \mathrm{mg} /$ $\mathrm{ml}$ concentration is the most effective dosage for all the three chemical complexes used. It was also observed that as the incubation period increases, the inhibition on the fungal isolates increases. At optimum dose, there was 68.8, 85.6 and 90.0 percentage reductions in mycelial growth of Geotrichum candidum when Copper (II) complex of thiourea, $\mathrm{Ni}^{2+}+\mathrm{PAN}$ and $\mathrm{Ni}^{2+}+$ Azo respectively were used at 24 hours incubation period. Also, there was 60.0, 100.0 and 100.0 percentage reduction in mycelial growth of Collectotrichum capsici when Copper (II) complex of thiourea, $\mathrm{Ni}^{2+}+\mathrm{PAN}$ and $\mathrm{Ni}^{2+}+$ Azo respectively were used under similar conditions (Fig. 1-6).

\section{Discussion}

Pepper plants are subject to infection with many diseases (Demirci and Dolar, 2006; Lamp et al., 1999; Utkhede and Mathur, 2005). They are liable to be attacked by several soil-borne pathogenic fungi which are responsible for considerable plant mortality and consequently high losses in yield and quality in many parts of the world (Abada, 1994; Lu et al., 1984; Mushtaq and Hashmin, 1997). This study became of paramount interest in order to proffer possible solutions to the problem of post-harvest rottening of red pepper fruit. Rhizopus sp, Mucor sp, Collectotrichum capsi-

Tab. 1. Fungi isolated and identified from diseased Pepper fruits (Capsicum annum)

\begin{tabular}{cc}
\hline Isolates & Fungi identified \\
\hline (A) & Mucor sp \\
(B) & Rhizopus sp \\
(C) & Geotrichum candidum \\
(D) & Collectotrichum capsici \\
\hline
\end{tabular}




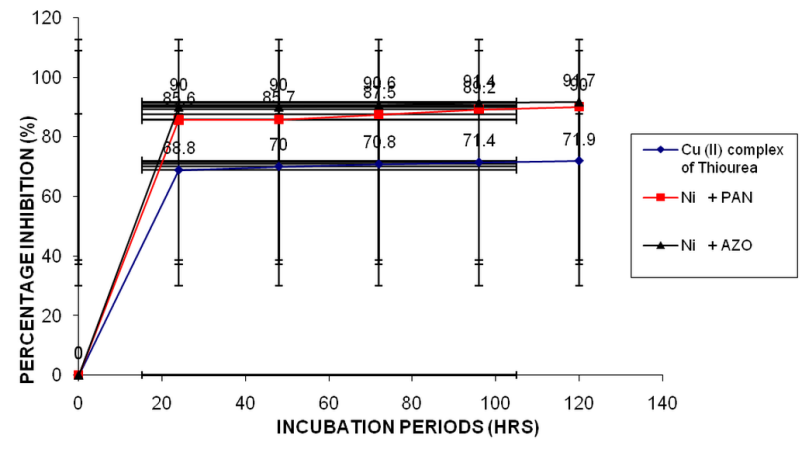

Fig. 1. Reduction of Mycelial growth of Geotrichum candidum at $10 \mathrm{mg} / \mathrm{ml}$

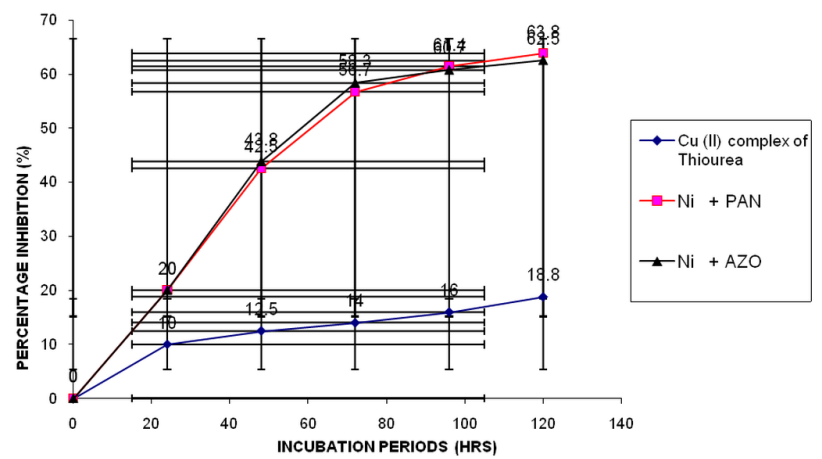

Fig. 3. Reduction of Mycelial growth of Geotrichum candidum at $0.1 \mathrm{mg} / \mathrm{ml}$

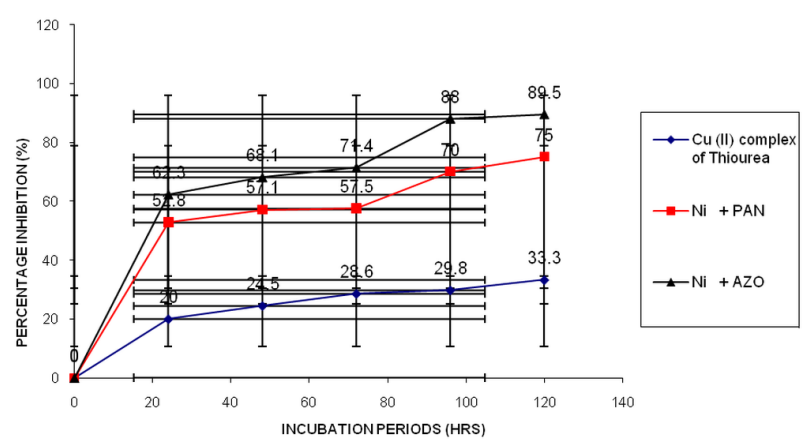

Fig. 5. Reduction of Mycelial growth of Collectotrichum capsici at $1.0 \mathrm{mg} / \mathrm{ml}$ concentration

$c i$ and Geotrichum candidum were isolated from diseased pepper fruits (Tab. 1). Rhizopus sp. Collectotrichum capsici and Geotrichum candidum were also associated with post harvest rot of tomato by Naureen et al. (2009). Two of the isolates, Collectotrichum capsici and Geotrichum candidum, were found to be pathogenic to the pepper fruit, a similar result to this was obtained by Anna (1990) and Naureen et al. (2009).

Results indicated that the synthetic compounds $\mathrm{Cu}^{2+}$ + Thiourea, $\mathrm{Ni}^{2+}+$ Azo, $\mathrm{Ni}^{2+}+$ PAN showed inhibitory effect on the two pathogenic isolates (Fig. 1 to Fig. 6). This is in accordance with the report of Hakan et al. (2009). The optimum dosage was $10 \mathrm{mg} / \mathrm{ml}$ and it was observed that the greater the doses, the more effective the chemical. $\mathrm{Ni}^{2+}+$ Azo proved to be much more effective, systemic

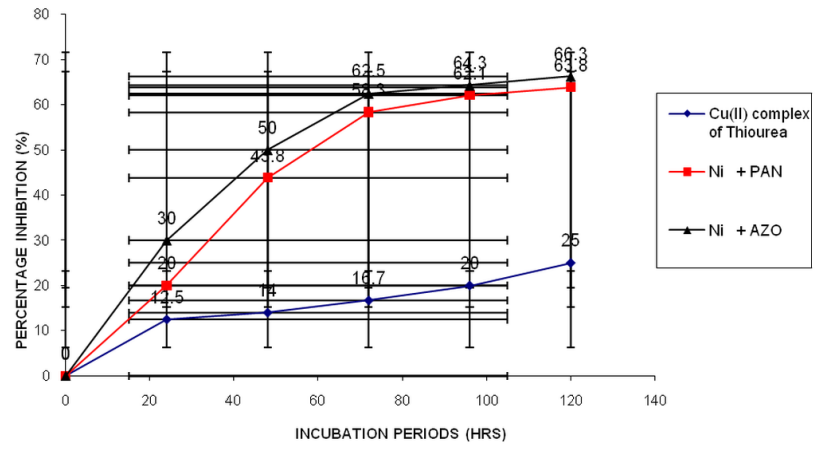

Fig. 2. Reduction of Mycelial growth of Geotrichum candidum at $1.0 \mathrm{mg} / \mathrm{ml}$

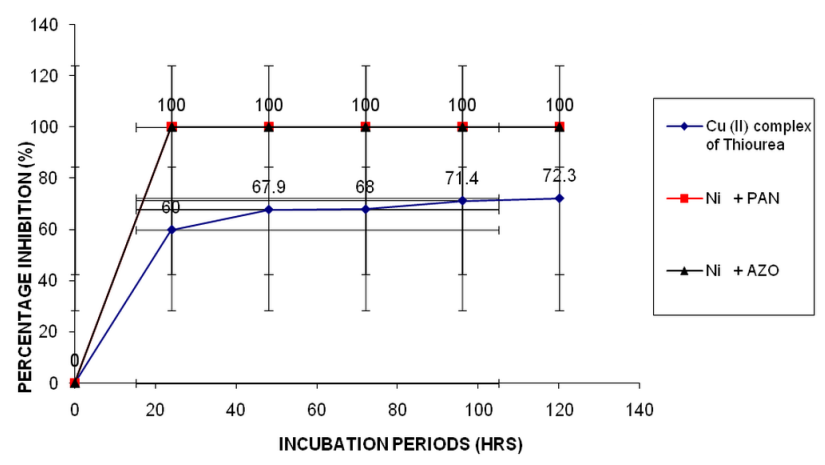

Fig. 4. Reduction of Mycelial growth of Collectotrichum capsici at $10 \mathrm{mg} / \mathrm{ml}$ concentration

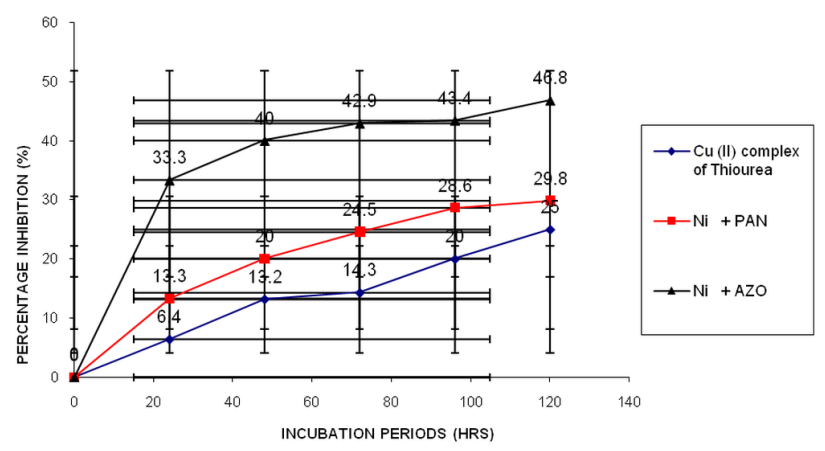

Fig. 6. Reduction of Mycelial growth of Collectotrichum capsici at $0.1 \mathrm{mg} / \mathrm{ml}$ concentration

and microcidal while chemical complex of Copper had the lowest inhibitory effect on the two isolates. The effectiveness of $\mathrm{Ni}^{2+}+\mathrm{Azo}$ is as a result of it's ability to inhibit iron oxidation and $\mathrm{CO}_{2}$ fixation in the microorganism. Smith (1967) had similar result of this action of nickel when he worked on strains of Thiobacillus thioxidans and Thiobacillus feroxidans. The low inhibitory effect of chemical complex of Copper on the two isolates irrespective of the concentrations used was basically due to the constituents of the chemical complex of Copper, which consists of Oxalic acid, Cobalt chloride $\left(\mathrm{CoCl}_{2}\right)$ and Thiourea. The Oxine or Oxalic acid in the chemical complex of Copper forms a chelate with Cobalt and since Cobalt has a weak toxicity so that of Copper Cobalt-Oxine complex formed is weak making it insoluble in water to permit penetration 
48

of the liquid barriers in the fungal cell. This finding is in consonance with the work done by Warthing and Hance (1991). Also, Oxine or 8-hydroxyquinoline, a derivative of Oxalic acid present in the chemical complex of Copper, is a protectant fungicide which when suitably formulated appears to possess limited systemic action (Green, 1984; Hassal, 1990).

\section{Conclusion}

The advantage derived from the use of the synthetic compounds makes it a suitable fungicide of choice. Ingestion of soluble salts of Copper in sufficient concentration gives rise to gastroenteritis (Whaeterall et al., 1986). Therefore, further research into the toxicity effect of the compound will be of interest for further studies.

\section{Acknowledgements}

The authors appreciate the effort of Professor Obaleye for providing the chemical compounds used for this work.

\section{References}

Abada KA (1994). Fungi associated with root rot of pepper and some factors affecting disease incidence. $7^{\text {th }}$ Congress of Phytopathology, Giza 220-226.

Agrios GN (2005). Plant pathology. Academic Press, New York.

Anna LS (1990). A colour Atlas of post-harvest diseases and disorders of fruits and vegetables. General Introductions and Fruits. Vol. 78-79.

Avakyan ZA (1974). The toxicity of heavy metals to microorganisms. 3-28 p.

CMI $(1985,1988)$. Description of pathogenic fungi and bacteria. Commonwealth Mycological Institute Kew, Survey.

Croxal HG, Gwynna DC, Jenkins JE (1952). The rapid assessments of apply scab on fruit. Pathology 1:89-92.

Demirci F, Dolar FS (2006). Effects of some plant materials on phytophthora blight (Phytophthora capsici Leon.) of pepper. Turkish Journal of Agriculture, 247-252 p.

Fagbemi TN, Soyinka AC (1988). Mineral composition of Tropical chillies (peppers). Unpublished paper delivered at the $20^{\text {th }}$ conference of Nutritional Society of Nigeria.

Green MB (1984). Fungicidal chemistry, advances and applications. American Chemical Society Washington, 420-422 p.

Hakan A, Nizami D, Gulay B, Cemal KO, Cevdet A (2009). Antimicrobial activity of some Thiourea derivatives and their Nickel and Copper complexes. Molecules 14:519-527.
Hassal KA (1990). The biochemistry and uses of pesticides. Macmillan, London, 286 p.

Kader AA (2002). Post-harvest technology of horticultural crops. University of California, Agriculture and Natural Resources, Pub 3311.

Kelman A (1984). Post-harvest pathology of fruits and vegetables, 1-3 p. In: Moline HE (Ed.). Post-harvest losses in perishable crops. University of California Agricultural Experimental Station Bulletin.

King RC (1974). Plant viruses and protists. Edited Handbook of Genetics. Vol. 2.

Lamp EM, Sonoda RM, Oxman EF, Curry JE (1999). Identification and incidence of Fusarium stem rot in greenhouse peppers in south Florida. Proc Fla State Hort Soc 112:308 9.

Lu JY, Yu CF, Ju LH (1984). Studies on differentiation of the virulence of Verticillium dablia on pepper. Acta Phytopathologia Scientia 14(4):213-18.

Luken RJ (1971). Chemistry of fungicidal action. Chapman and Hall, London.

Marsh RW (1977). Systemic fungicides. $2^{\text {nd }}$ Edition, Longman, London.

Mushtaq M, Hashmin MH (1997). Fungi associated with wilt disease of Capsicum in Sindh, Pakistan. Pakistan Journal of Botany. 29(2):217-22.

Naureen F, Humaira B, Viqar S, Jehan A, Syed E (2009). Prevalence of post-harvest rot of vegetables and fruits in Karachi. Pakistan Journal of Botany 41(6):3185-3190.

Phatak SS, Patwardhan VN (1985). Toxicity of Nickel. Accumulation of Nickel in rats fed with Nickel containing diets and its elimination. Science Ind Research Vol. IIB 173-176.

Purseglove JW (1991). Tropical crops dicotyledons. Longman, London, $720 \mathrm{p}$.

Smith DH (1967). Factors mediate resistance to Mercury, Nickel and Cobalt. Science 50:114-115.

Stokinger HE (1963). Industrial hygiene and toxicity, 987-992 p. In: The metals, $2^{\text {nd }}$ Edition,Vol. 2.

Utkhede RS, Mathur S (2005). Biological and chemical control of fruit rot in greenhouse sweet peppers (Capsicum annum L.) caused by Fusarium subglutinans. Journal of Biological Science 5(5):610-615.

Warthing CR, Hance RJ (1991). Pesticides Manual. 9th edition. British Crop Protection Council Croydon, 219-222 p.

Whaeterall DJ, Ledingham TGG, Warrel DA (1986). Toxicity effect of Copper accumulation on man, $949-950$ p. In: Oxford Textbook of medicine. $2^{\text {nd }}$ Edition, Vol. 1. 